\title{
Academic Cheating In Higher Education The Effect of A Student Development Approach A Study At UniversitiTeknologi Malaysia
}

\author{
Mahmoud Poorian ${ }^{1}$, MohammadJavadNekooei $^{2}$,Yusof bin boon ${ }^{3}$ \\ ${ }^{1,3}$ Department of Educational Foundations, Faculty of Education, UniversitiTeknologi Malaysia \\ ${ }^{2}$ Department of Engineering ,Faculty of Engineering ,Islamic Azad University Safashahr branch ,Fars ,Iran
}

\begin{abstract}
Faculty, students, and administrators are the most important concerns regard toacademic dishonesty concern in higher education. The research aims to provide a proper knowledge about the problem and also methods for the solution. Dr. William Kibler(1992) provideda Framework for solvingacademic Dishonesty in higher education. astudentdevelopment Perspective was used for the aim of his study.Kibler deployed a student development perspective instead of other common method called behavioral approach. His study aimed to discover the survival of academic dishonesty in higher education. It also aimed to determine the institutions knowledge about developmental approach application to tackle this concern. This study aims to find the level of existence of an academic dishonesty in higher education environments(eg.uiversititeknologi Malaysia).
\end{abstract}

Keywords -Academic Dishonesty, Student Development, Higher Education,Education Environment

\section{Introduction And Background}

Faculty and students are encountered to academic dishonesty in today's academic environments like colleges and universities (May \&Loyd, 1993). It can also be extracted from May and Loydstudythat the high level of academic dishonesty has motivatedextra research. Additional studies should be donein order to achieve improved knowledge aligned with the reason of academic dishonesty. These studies can lead to methods preventing this problem. Academic dishonesty Goal of higher education can be affected by academic dishonesty.It can also causechallenges to knowledge pursuit (Lambert, Hogan, \& Barton, 2003). This study aims to find the level of existence of an academic dishonesty in higher education environments. This study is a regeneration of William Kibler study in 1992.Institutions' policies wereconsidered tocontrol incidents of academic dishonesty. The research was done using asurvey on previous and presentdone on this topic. It includes honor code systems' basic componentsmade toconflictacademic dishonesty. An assessment on astudent development approach impacts was also done to tackle higher education academic dishonesty. A comparison was made between data achieved by this study .

\subsection{Research Background}

Llack of academic integrity is implied by the academic dishonesty existence(Altbach, 2004). A tradition recommitting including integrity and honor is necessary for American higher education institutions McCabe and Trevino (2002). Altbachdefines the lack of integrity resulting from the pressure imposed to academic institutionsin order tosupplyidenticaladmission for students duringstudents' degree programs completing session. Scope of education is comprised by Academic dishonesty. It alsoimpacts honest students and passionate faculties about teaching and learning (Lambert et al., 2003).

A communication approach about cheating long-term effects of plagiarism should be deployed to notify students. honoring truth importance should also be alarmed. Integrity should also be maintained by stundets' understanding and participating in activitiesMoore (2002). Lipson (2004) count three principles of academic honesty as follows:

[a] Tell you have done the work if it has actually been done by you

[b] Cite someone works if you have used it

[c] Presentresearchmaterials fairly and truthfully .

all classes, labs, papers, and exams should deploy these principles. They are very simple and easy to learn. Using these principleseradicatemany academic dishonesty infractions (Lipson, 2004).

Academic dishonesty efforts can be expanded by world wild web accessible for all students. Many studentsconsider this type of treacherytrue Houghton and Heberling (2006). They consider Internet as a secondary source of knowledge to be deployed at their discretion (Houghton \&Heberling).

Institutionsmake honor codes as an approach toguarantee academic integrity (Lipson, 2004). A pledge sign accepting to do truthful work, observe classmates, and account violations is needed for an usual honor code (Lipson). The difference in honor code schools is students' responsibility feeling topreserve and endorse high standards and integrity. Honor provides animportanteffect on participating campuses. It indicatesthe likelihood of producing positive results made byefforts to decrease academic dishonesty (McCabe \& Trevino, 2002). 


\subsection{Problem Statement}

\section{Objectives, Problem Statements}

Higher education academic dishonesty is the problem investigated by this study

Students can be engaged in academic dishonesty activities by using of increasing avenues

Programs and policies considered to decrease academic dishonesty were reviewed by this study.

\subsection{Goal of the Study}

Goals of the study are classified as follows:

(a) Recognize and explainpresentactivitiesdeployedin higher education to tackle academic dishonesty

(b) Establish and assess the designed programs extent to be developmental, and

(c) Evaluate the judicial officers' viewsconcerning academic dishonesty programs usage and developmental practices in nature.

\section{Literature review}

A comprehensive review on the available literature offeredcritical information on the background of this research.Mainspotlight areas can be determined by a survey in the available literature. Policies concerning about institutionscontaining student rights, disciplinary sanctions, and due-process procedures are criticalfor a campus climate development that promotes academic integrity. Judicial officers are influentialto guide the judicial procedure in a reasonable and neutralapproach. Enforcement of disciplinary policies can be strengthen by the aim of faculty collaboration. Internal personal issues and external situational conditions account for the primary reasons that students violate academic dishonesty policies violation done by the students can be related to both personal internal and external situational condition. A lot ofvariedcauses were offered;even if research does not offer a specificrationale showing academic dishonesty act engagement bystudents.

Students can entrustacademic dishonesty by extra chances provided by technology. Plagiarisms can be detected by the resources available for the faculties.Academic integrity promotion can be enhanced by faculty participation. This concern can be solved by the guidelines provided for the faculties. An integrity climate on college campuses can be established by honor codes mentioned before by the faculties. Private colleges still deploy Traditional honor codes due to severe requirements of them. Studentparticipation can be commanded by modified honorcodes. They can be managed comparing to traditional honor code.

Academic and behavior actions of students can be explained by students' development theory.Information extracted from them is helpful in academic dishonestyaddressing. A educational component will be provided to a judicial process using a developmental approach.

\section{Methodology And Research Design}

A survey approach is used for the aim of this study. A research based on a survey methodoffers a methodicalloom to explaintendency, approach, or viewsof a specificinhabitants by the aim of data achieved from them (Creswell, 2003). Questionnaires are used to measure a particular topic interest among the selected population (Martella, Nelson,\&Marchand-Martella, 1999). Thequestionnaireshould be designedefficiently to collectessentialresponsesMartella et al.(1999) Dr. William Kibler(1992) research results were replicatedon academic dishonesty by this study.

\subsection{Research questions}

ascreated by Kibler, mentioned in this study comprise

1.Are there policies deployed by institutions of higher education preventing academic Dishonesty?

2.Can academic dishonesty be properly addressed from astudent development viewpoint?

3.Is there any program for promoting academic integrity for institutions of higher education aim to exclude academicdishonesty?

4. How programs' componentstackle academicdishonesty from a student point of view?

5. What obstacles can be deployed for institutions of higher education to response to students academic dishonesty found guilty?

6. What obstacles are reallyforced by the organizationsregard to students' academic dishonesty foundguilty?

7.Are the obstacles considered in reaction toacademic dishonesty comprise student development interferences?

8. Respondent recommend

The aim of this study is tocollectprecise and presentdataconcerning academic dishonesty topic.

Kibler(1992) study replication showedpresent academic dishonesty activitiesexisting in higher educational institutions, containing programs and policies. An evaluation was conducted to settle ondevelopment approach incorporation of programs and practices. 


\subsection{Research Design}

A survey based studydeploys questions or interviews for the aim of data collection (Gall, Gall, \& Borg, 2003). A questionnaire based study was conducted in order to the data collection of this study..A descriptive statistics approach was deployed in order to analyze the collected data precisely. Study research questions were answered with the aim of this research design.

\subsection{Sample Selection}

This study deployed the students of university technology Malaysia as the population who will be surveyed to provide current data to respond to the research questions.

\subsection{Data Analysis Procedures}

Data extracted from completed questionnaire was investigated for the purpose of reporting. Following information is compiled:

1. Total number of respondents

2. Number of technical institutions

3. Number of social institutions

4. Number of community colleges

5. Response rate

6. Percentage of respondents

7. Percentage of non respondents

Each research question was investigated for the aim of results reporting. Each question provided adividedexplanatory finding report.

\section{Results} brought out.

After collecting the research question papers from three faculties, Consequently, the following results

1. Total number of respondents : 300 STUDENT

2. Number of technical institutions: 1

3. Number of social institutions: 1

4. Number of community colleges: 1

6. Percentage of respondents: 89 PERCENT

7. Percentage of non respondents: 9 PERCENT

In below we located some students responses to the questionnaire from three faculty .

\section{IBS (international business school )}

1- Yes, certainly

2- It depend on the implementation of those policies

3- Yes, but they are not transparent for almost all students

4- They are very narrow that show academic dishonesty

5- Failing

6- To refuse from some subjects

7- So much

8- It is great and unique

\section{FKA (faculty of civil engineering )}

1- Most of the universities have policies on the academic dishonesty

2- they address academic dishonesty obviously

3- Most universities /institutions have some program for this purpose

4- So much

5- Failing

6- They will prohibit students from study and paying fine also.

7- Not So much

8- It helps university authorities to promote their policies

\section{FS (faculty of science)}

1- Yes, every institution has the policies on prohibiting academic dishonesty

2- It depends on university

3- Yes, they have

4- Not so much

5- Failing

6- Refusing 
7- Some institutions and universities perform strict rules and some are not.

8- It is practical and useful for every university

\section{Discussion on the finding}

After collecting the research question papers from three faculties, responses came together and analyzed one by one. Consequently, the following results brought out.

1- Almost all of the students specified toughly that institutions of higher education have policies in order to prohibit academic dishonesty.

2- Even though institutions address academic dishonesty, nevertheless effective implementation depends on institution or university strategies.

3- All students reach agreement each institution has some program for this purpose, but they are not transparent for almost all students.

4- Components of academic dishonesty program at institutions about student development was measured from not so much to so much.

5- Most of the students believe "to fail" is the only tactic that most institution uses in response to students' academic dishonesty.

6- They identified institution often put on "to refuse, to forbid from some subject and to pay fine as reaction to academic dishonesty.

7- They believe sanctions used by the institutions in reaction to academic dishonesty has not much constitute in student development

8- They expressed the article is practical and valuable for every organization or university.

\section{Conclusion}

As a result, academic dishonesty procedures are applied and worthy, but then some institutions do not pay attention seriously. Application of these strategies performance a significant starring role in promoting quality of academic productions and motivating researchers. Besides, it draws a vibrant pathway for future educational activities.

\section{Reference}

[1] Altbach, P. (2004, Winter). The question of corruption in academe. International Higher Education, 34, 1-3. Retrieved September 5, 2006, from http://www.bc.edu/bc_org/avp/soe/cihe/newletter/news43/textoo4.htm

[2] Amig, S. (2001, March/April). Harnessing the power of distance learning. BehavioralHealth Management, 21(2), 12-13.

[3] Association for Student Judicial Affairs. (2007). History of ASJA. Retrieved July 1, 2006, from http://www.asjaonline.org

[4] Baird, J. (1980). Current trends in college cheating. Psychology in the Schools, 17(4), 515-622.

[5] Bell, D. (2005, March 1). Encouraging faculty to report cheating. Scholastic, 33(5), 1-2

[6] Bolin, A. (2004). Self-control, opportunity, and attitudes as predictors of academic dishonesty. The Journal of Psychology, 138(2), 101-114.

[7] Breen, L., \&Maassen, M. (2005). Reducing the incidence of plagiarism in an undergraduate course: The role of education. Issues in Educational Research,15(1), 1-12. Retrieved February 13, 2007, from http://www.iier.org.an/iier15breen.htm

[8] Callahan, D. (2007, April 15). Ten tips for talking about cheating. Student Affair Leader,35(8), 4.

[9] Center for Academic Integrity. (1999). The fundamental values of academic integrity. Retrieved February 7, 2007, from http://www.academicintegrity.org

[10] Center for Academic Integrity. (2007). Research on academic integrity. Retrieved February 7, 2007, from http://www.academicintegrity.org

[11] Christie, B. (2005, January). Course design, monitoring helps ensure academic honesty.

[12] Online Classroom, Ideas or Effective Online Instruction, 2-3.

[13] Creswell, J. (2003). Research design: Qualitative, quantitative and mixed methods approaches. Thousand Oaks, CA: Sage. 72

[14] Dannells, M. (1997). From discipline to development: Rethinking student conduct in higher education. ERIC Digest, 25(2), 2-6. Retrieved February 7, 2007, from http://www.ericdigest.org

[15] Evans, N., Forney, D., \& Guido-DiBrito, F. (1998). Student development in college. San Francisco: Jossey-Bass.

[16] Evcegoval, Z., \& Richardson, J. (2004, July). Academic dishonesty, plagiarism, included in the digital age: A literature review. College and Research Libraries, 301-318.

[17] Fass, C. (1986). By honor bound: Encouraging academic honesty. Educational Record, 67(4), 32-34.

[18] Fisher, J., \& Hill, A. (2004, November/December). Plagiarism in an electronic age. Library Media Connection, 18-19.

[19] Foster, A. (2002, May 17). Plagiarism-detection tool creates legal quandary. Chronicle of Higher Education, 48(36), A37. Retrieved February 22, 2007, from AcademicSearch Premier database.

[20] Gall, M., Gall, J., \& Borg, J. (2003). Educational research: An introduction. Boston: Pearson.

[21] Gehring, D. (2001). The objectives of student discipline and the process that's due: Are they compatible? National Association of Student Personnel Administrators Journal, 38(4), 466-481.

[22] Grijalva, L., Nowell, C., \&Kirkvliet, J. (2006). Academic honesty and online courses. College Student Journal, 40(1), $180-185$.

[23] Groark, M., Oblinger, D., \& Chou, M. (2001, September/October). Term paper mills, anti-plagiarism tools and academic integrity. EDUCASE Center for Applied Research, 40-48.

[24] Hall, L., \&Kuh, G. (1998). Honor among students: Academic integrity and honor codes at state-assisted universities. National Association of Student Personnel Administrators Journal, 36(1), 2-13.

[25] Hansen, B. (2003). Combating plagiarism: Is the Internet causing more students to copy? CQ Researcher, 13(32), 773-796.

[26] Holcomb, T. R. (1992). A case study analysis of honor codes at six institutions of higher education. Retrieved October 19, 2006, from ProQuest database. 